\title{
Assessing Social Equity in Farmer- Managed Natural Regeneration (FMNR) Interventions: Findings from Ghana ${ }^{\mathrm{a}}$
}

\author{
Matt Kandel, Genevieve Agaba, Rahinatu S. Alare, Thomas Addoah and Kate Schreckenberg
}

\begin{abstract}
Achieving social equity in land and forest restoration is a key objective of major international frameworks and commitments, including the UN Decade on Ecosystem Restoration. Meeting this objective requires consideration of key governance questions such as who makes decisions about what is restored, where, and how? And how do factors specific to local contexts influence which decisions are made, and, in turn, the distribution of benefits? Despite the demonstrated importance of social equity on project outcomes in many natural resource-based fields, there have to date been no assessments of social equity of farmer-managed natural regeneration (FMNR), an approach used mainly for restoring degraded agricultural land. Drawing on findings from community-based fieldwork in 2019-2020 in northeastern Ghana, this paper aims to fill this void. We address the following question: How do historical, socio-ecological, and political processes condition prospects for social equity in FMNR interventions? Key findings were: 1) Preexisting hierarchies in authority, control, and access over land and trees shaped decision-making in project design and the potential distribution of benefits from FMNR 2) FMNR, when implemented on farmland, generally aligned with local agroecological practices; but, when implemented to restore communal lands, it created tensions with local perceptions of equity as well as traditional land and natural resource management practices, and 3) The FMNR project reflected the continuing salience of dominant political and environmental discourses, which carry implications for restoring landscapes with FMNR. To support practitioners, we provide several recommendations for strengthening social equity of FMNR project designs.
\end{abstract}

Keywords: African drylands, farmer-managed natural regeneration (FMNR), natural resource governance, social equity, tenure

\section{\$) Restoration Recap (\%)}

- To avoid negative trade-offs, FMNR projects should consider social equity from the outset, which means recognizing the varying aspirations of different stakeholders in the landscape and putting in place processes needed to overcome contextual inequity and achieve equitable distributive outcomes.

- Recognizing and strengthening the participation of diverse local land users in FMNR project designs might improve restoration outcomes, as demonstrated in other natural resource-based fields.
- Conducting tenure assessments prior to the implementation of FMNR projects will allow for identifying which stakeholders in the landscape experience tenure insecurity. Evidence suggests this is important for mitigating inequitable restoration outcomes.

- If FMNR is paired with enrichment planting due to insufficient natural regeneration, special attention should be paid to how tenure regimes condition authority over land use decision-making and control and access over tree products. a This open access article is distributed under the terms of the CC-BYNC-ND license (http://creativecommons.org/licenses/by-nc-nd/3.0) and is freely available online at: http://er.uwpress.org

Ecological Restoration Vol. 39, Nos. 1-2, 2021

ISSN 1522-4740 E-ISSN 1543-4079

(C2021 by the Board of Regents of the University of Wisconsin System.

\begin{abstract}
A chieving social equity in land and forest restoration is a key objective of major international frameworks and commitments such as the UN Decade on Ecosystem Restoration (2021-2030), Bonn Challenge, and African Forest Landscape Restoration Initiative (AFR100). The Society for Ecological Restoration's guidelines for practitioners similarly emphasize the importance of integrating principles of equity and social inclusion into the design of restoration
\end{abstract}


interventions (Gann et al. 2019). These commitments to social equity are underpinned by a wide body of research, particularly in the broad field of community-based natural resource management. This literature demonstrates the importance of addressing key governance questions such as who makes decisions, who benefits, and who loses out (McDermott and Schreckenberg 2009). As recently highlighted by Hajjar et al. (2020), community forestry cases in which environmental, income, and natural resource rights outcomes are all positive are relatively rare. Local perceptions of social inequity might facilitate resistance to or a lack of participation in community forestry (Cronkleton et al. 2012, Baynes et al. 2015, Gross-Camp et al. 2019), and evidence links the effectiveness of protected area management to whether local land users feel empowered to make decisions (Woodley et al. 2012, Oldekop et al. 2016). Furthermore, natural resource-based interventions are not implemented in an historical vacuum; rather, they are embedded within preexisting social norms and relations of power, which may disproportionately benefit certain groups at the expense of others (Colfer and Capistrano 2012, Nunan et al. 2018, Libert-Amico and Larson 2020).

Given the long-established concerns about social equity in the wider natural resource governance literature (Edmunds and Wollenberg 2003, Ribot 2004), it is slightly surprising that so little attention has been paid to social equity of farmer-managed natural regeneration (FMNR), although a few have identified the gap (Reij and Winterbottom 2015, Binam et al. 2017). FMNR is a type of agroforestry based on managing plants arising from resprouting rootstock or from seeds in degraded agricultural land (Chomba et al 2020). FMNR was developed as a land restoration approach in the 1980s by Tony Rinaudo, an NGO practitioner (Tougiani et al. 2009). He sought to support the natural regeneration of trees and shrubs through traditional management practices, such as coppicing and pollarding, in order to address widespread tree loss and the chronic failures of tree planting interventions in semi-arid Niger (Rinaudo 2007, Tougiani et al. 2009). As Hansen et al. (2012) and Binam et al. (2017) note, FMNR, given its focus on managing and protecting naturally regenerating trees and shrubs, shares similarities with the traditional agroecological practices of farmers in the West African parklands, an agroforestry system based on the deliberate retention of scattered trees in continuously cropped fields and long-term fallows (Boffa 1999). While a recent systematic review raises important questions regarding the attribution of certain environmental and social outcomes to FMNR (Chomba et al. 2020), evidence links FMNR to improvements in carbon sequestration, biodiversity, crop yields, and poverty alleviation (Reij and Garrity 2016, Bayala et al. 2020), and it has been credited with restoring seven million hectares of agricultural land in Niger (Smale et al. 2018).

As FMNR continues to be scaled out across Africa and south Asia (Moore et al. 2020), implementing organizations must grapple with the socio-ecological, political, and historical complexities of intervention contexts, as well as consider whether FMNR aligns with local understandings of agroecological processes. Providing an empirical evidence base for why FMNR projects should grapple with these complexities is particularly important given that, at least to our knowledge, there have been no assessments of social equity of FMNR to date. This paper, which reports on findings from community-based fieldwork in 2019-2020 in northeastern Ghana, therefore aims to fill this void. We address the following question: How do historical, socioecological, and political processes condition prospects for social equity in FMNR interventions? By engaging with this question, we aim to provide useful insights for both researchers and FMNR practitioners (see also Kandel et al. 2020 for a practice brief). We further aim to contribute to the expanding literature evidencing why the social and political dimensions of land and forest restoration deserve our full attention (Elias et al. 2021, Chazdon et al. 2020a). This is especially timely given the rush to scale up ecosystem restoration, as encapsulated by the new UN Decade.

The next section provides the historical background to contemporary land and natural resource governance and tenure in northern Ghana. Following this we present our methodology, which includes descriptions of the FMNR intervention and our study site. We then present our results and discuss our findings. This is followed by the conclusion, where we provide several recommendations for practitioners with regard to improving social equity of FMNR.

\section{Historical dimensions}

\section{Forestry policy and discourses in northern Ghana}

Contemporary natural resource management and governance in northern Ghana have been shaped by historical developments, including colonial forestry policies and dominant environmental discourses. Since the dry forests of northern Ghana lacked timber considered valuable at the time (this view has recently changed due to international market demand for Pterocarpus erinaceus [African rosewood] [Dumenu and Bandoh 2016]), colonial forestry policies differed from those implemented in the south, where the High Forest ecological zone formed the basis of the timber industry (Wardell 2020). In the north, colonial forestry policies were premised on soil and water conservation, anti-bush burning, and headwaters protection (Wardell 2020). Suppressing savanna and agricultural fires, a preoccupation of colonial administrations across dryland West Africa, was seen as necessary to preserve dry forest and prevent the "savannization" of forest in the central Ghanaian ecological transition zone (Laris and Wardell 2006).

Colonial land and natural resource policies in the north were heavily influenced by dominant environmental discourses. This included the "deforestation-desiccation" 
narrative (Wardell 2020), of which one school of thought held that local resource management practices in the drylands degraded the environment to such an extent that desiccation was the inevitable outcome. These environmental discourses shaped key debates over the appropriations of customary lands. For instance, the 1947 North Mamprusi Forestry Conference debated evicting and resettling 70,000 people in the densely populated northeast in order to prevent soil erosion and establish headwaters protection forest reserves (Wardell et al. 2003). Despite the role of the colonial state in appropriating customary lands, land and natural resources remained governed by a combination of statutory and customary laws, which laid the grounds for the contemporary context of legal pluralism in Ghana (Akaateba 2019).

\section{Land and tree tenure in northeastern Ghana}

Land tenure in northeastern Ghana is characterized by the coexistence of plural systems of governance. The 1992 Constitution, which identifies customary land as one of the legal types of tenure in Ghana (Ubink and Quan 2008), specifies that the allodial title is vested in traditional authorities, families, or clans. In the northeast, this means traditional authorities hold ("own") the land in trust on behalf of communities. In parts of the region where centralized chieftaincy systems historically predominated, chiefs mediate the allodial title (Akaateba 2019). However, vast areas of the northeast were first settled by ethnic groups with decentralized political systems, including the Talensi. Amongst these ethnic groups, the Tindana or Tengynono (spiritual custodian of the earth), not the chieftaincy, is the customary institution most readily identifiable as a traditional land authority (Konings 1984). While authority and control over land for these groups was historically based on first clearance and settlement of land (Millar 2003), colonial and postcolonial governments have historically supported the chieftaincy against the Tindana (Konings 1984), creating tensions between the two traditional authorities (Lund 2008). While there is variation, migrant ("latecomer") lineages often cannot contest for the chieftaincy and on principle cannot mediate the Tindana-the exclusive right of firstcomers (Lund 2008). Firstcomer lineages often use the claim of "first to settle" as the basis for restricting the land use decision-making of latecomers (Lentz 2010).

Usufruct rights, which are based on patrilineal inheritance, are controlled by senior men who manage land on behalf of their household (Akaateba 2019). Usufructuaries in the northeast often interpret their land rights in terms of "ownership" given the wide scope they generally have for making land management decisions. Another way people acquire access to land is through secondary rights, granted either by a usufructuary or allodial rightsholder. For instance, in northeastern Ghana, where kinship is based on patrilineality and virilocality (women leave their natal area upon marriage to live with their husbands), women acquire rights to land through their husband (Fortes 1949). Migrants, including sedentarized pastoralists (mainly Fulani), and tenant farmers depend on secondary (leasehold) rights to land. However, the social positioning of Fulani remains perennially precarious due to pervasive anti-Fulani sentiment in Ghana (Soeters et al. 2017).

In both customary and statutory systems, governance of trees often differs from that of land (Fortmann 1985, Shepherd 1992). In Ghana there are significant ambiguities with regard to tree tenure (Ministry of Lands \& Natural Resources 2016). For instance, while all trees and forests are formally vested in the president, who holds them in trust for communities, there are no legal provisions stipulating how non-timber forest products (NTFPs) are governed (Ministry of Lands and Natural Resources 2016). Governance of trees in the northeast has historically been based on customary arrangements (Millar 2003).

\section{Methods}

\section{Study area}

Our fieldwork took place in Talensi district, located in the semi-arid Guinea-Sudanian zone of northeastern Ghana (Kansanga et al. 2019). Talensi is one of 11 districts in the administrative Upper East Region, of which the regional capital is Bolgatanga (Figure 1). There are two distinct seasons in northeastern Ghana: a rainy season (May to October) and a dry season (November to April). Average annual rainfall in Talensi is approximately $950 \mathrm{~mm}$ (Ministry of Local Government and Rural Development 2017). Soils are largely shallow, containing low levels of organic matter content (Kansanga et al. 2019). Talensi district is comprised mainly of the Talensi, a sedentary farming ethnic group, who, along with the Gurensi and Nabdams (both minority ethnic groups in the district), are referred to as "Frafra", a referent to their shared ethno-linguistic heritage (Hart 1971).

Livelihoods in northeastern Ghana are based largely on crop-livestock production, NTFPs, artisanal mining, wage labor at mining concessions, and labor migration to southern Ghana. In common with agricultural areas across the Sudano-Sahelian belt of West Africa, smallholder farmers in the northeast have historically managed their agricultural lands as parklands (Boffa 1999). Common parkland tree species in the northeast include Vitellaria paradoxa (shea) and Parkia biglobosa (African locust bean) (Wardell et al. 2003). Farmers often maintain two or three farms, including village-level plots, which are continuously cropped and may include homegardens; "bush farms" are fallowed and distal to their home compounds, and riparian plots are farmed mainly for market-oriented crops such as dry season vegetables (Wardell et al 2003). Livestock range freely during the dry season and are tied up in villages once the planting season begins. Mobile and sedentarized 


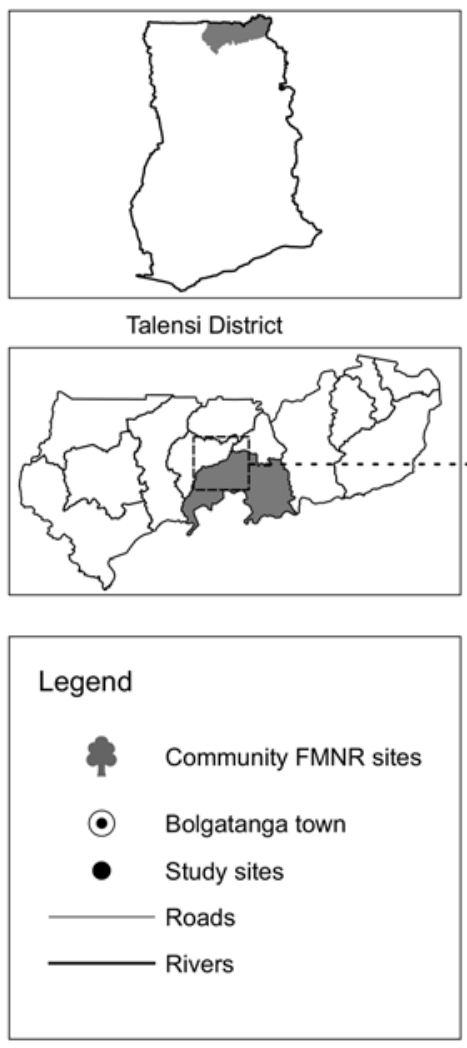

Figure 1. Map of study area.

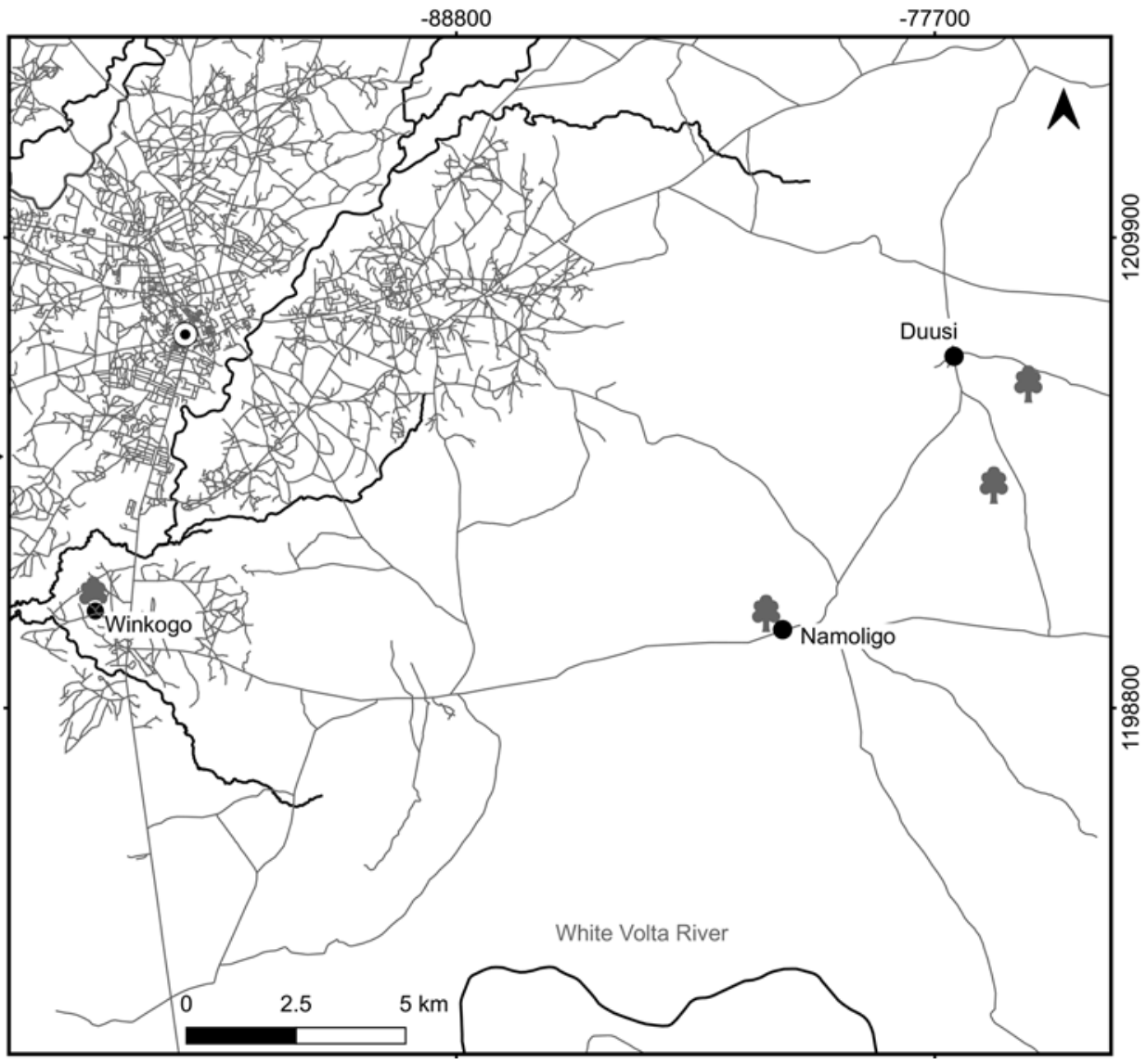

pastoralists also herd cattle in the region, particularly for chiefs and wealthy urban elites (Kuusana and Bukari 2015).

However, in recent decades the agropastoral production system has undergone significant, interrelated changes, all of which carry implications for land restoration based on assisted natural regeneration. These changes include increased reliance on conventional agro-inputs, such as mechanical traction (Kansanga et al. 2019), which may influence how trees are managed on farms (Arnold and Dewees 1997); shortened or eliminated fallow periods (Dietz et al. 2004), which influences the potential for natural regeneration (Lohbeck et al. 2020); cropland expansion (Kleeman et al. 2017), which has increased competition over land between farmers and mobile herders (Wardell et al. 2005); and deforestation, including increased cutting of $V$. paradoxa for charcoal production (Lovett 2018). The deepening commoditization of NTFPs, including of fruitbearing exotics and natives such as $V$. paradoxa (Lovett 2018), is likely to alter tree management practices in the fallows and woodlands (Boffa 2015).

\section{Theoretical framework}

For our analysis of social equity of FMNR, we adapt the McDermott et al. (2013) multi-dimensional equity framework (as redrawn by Pascual et al. 2014), which was designed for use in the context of the changing value of ecosystem services and has been applied to the analysis of payment for ecosystem services schemes (Pascual et al. 2014) as well as REDD+ initiatives (Chomba et al. 2016). This framework (Figure 2) is particularly suited to our study because of its emphasis on "contextual equity," which refers to "the uneven playing field" that is "created by the pre-existing political, economic and social conditions under which people engage in and benefit from resource distributions - and which limit or enable their capacity to do both" (McDermott et al. 2013). The concept of contextual equity aligns with our focus on how socio-ecological, political, and historical processes condition prospects for social equity of FMNR. In this framework, contextual equity conditions the distributive (how benefits, costs, and risks are distributed), procedural (the decision-making processes that lead to resource allocation), and recognition (respect for plural knowledge systems, values, norms, and rights of all stakeholders) dimensions of equity. Combining several components of the original McDermott et al. (2013) framework, our framework further highlights the need to consider who (if anyone) frames equity in the context of FMNR, underscoring that what constitutes equity may differ depending on the scale or stakeholders being considered.

\section{FMNR intervention}

In 2009, the international NGO, World Vision, piloted FMNR in nine communities in Talensi district (Weston 


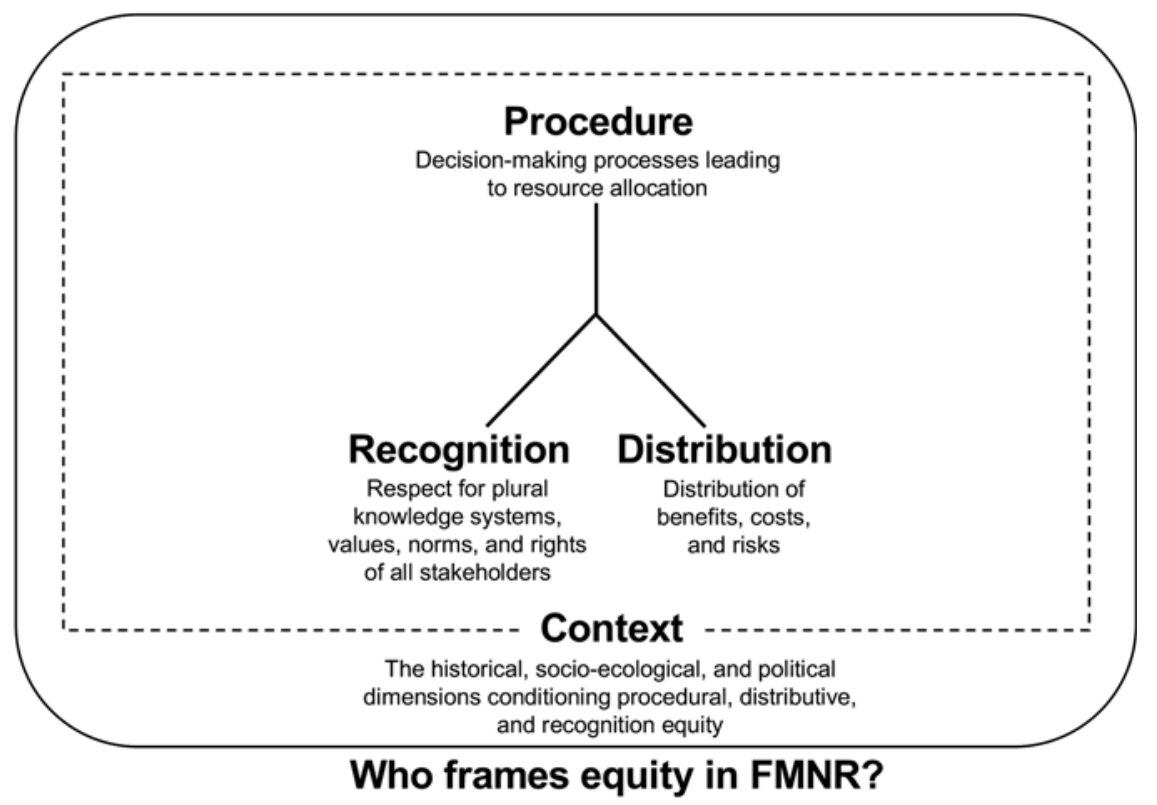

Figure 2. Framework for assessing social equity of FMNR (adapted from Pascual et al. 2014).

et al. 2013), and then scaled it out across northern Ghana (World Vision Australia 2019). The aim of the intervention was to address deforestation, land degradation, and the effects of climate change on issues such as food security (Weston et al. 2013). In each community, 20 farmers were selected to serve in an FMNR Group and another 20 served as Fire Volunteers, tasked with preventing and extinguishing bush fires in their communities (Weston et al. 2013). FMNR Group members were trained in FMNR to support on-farm adoption and knowledge sharing in their communities. The training occurred on community FMNR sites, which typically consisted of degraded land or woodland and were created based on an agreement between the NGO and community stakeholders. These stakeholders included the chief, district assemblyman, and senior men from household(s) which consented to their household land being converted into a community FMNR site and henceforth governed as a common property resource. Based on key informant accounts and our own observations, the sites ranged from approximately 0.5 to 40 hectares. Along with serving as training and demonstration grounds, the community FMNR sites were also supposed to be managed with FMNR by the FMNR and Fire Volunteer Group members. The aim was for these volunteers to use FMNR to turn these sites into "community forests" (Weston et al. 2013). Natural resource by-laws, supported by the chief, were created in each community and included prohibitions against burning village land (for any purpose) and cutting wet or dry trees on the community FMNR sites. The community sites were also intended to serve as a woodlots, with the pruned branches serving as a sustainable source of wood-fuel for households (Weston et al. 2013).

\section{Study design, data collection, and analysis}

The study consisted of three phases of qualitative data collection and analysis (see Table 1). Throughout the entire study each field team member (excluding the interpreters) practiced participation observation, based on an ethnographic research approach (Bernard 2000), which consisted of recording field observations and informal conversations with participants in field notebooks. Ethical approval was received from internal review boards at the University of Ghana and University of Southampton. Talensi was selected as the study district because it had the longest history of FMNR implementation by an NGO in northern Ghana (Weston et al. 2013). A main criterion for community selection was that an FMNR project had been implemented in the community (see Table 2 for characterizations of all three study communities). Community data collection occurred on village farms, bush farms, community FMNR sites, and in fallows.

\section{First phase of data collection}

In May 2019, we held a meeting with World Vision at their Talensi office to learn more about the aims and scope of the FMNR project. We then conducted interviews with key informants $(n=23)$, including government officials, technical experts in landscape restoration, and researchers. Interviewees were asked about their perspectives on FMNR, land use change, and land and natural resource management and governance in northern Ghana. We also acquired entry into Duusi, one of three study communities (along with Namoligo and Winkogo, Figure 1). As part of scoping in Duusi we conducted a community-scale transect walk, on-farm transect walks $(\mathrm{n}=3)$, and focus group discussions $(\mathrm{n}=3)$. These activities were conducted to develop an understanding of livelihoods, local ecological 
Table 1. Description and sample size for each data collection tool, together with information on where and during which research phase(s) each tool was used.

\begin{tabular}{|c|c|c|c|}
\hline Data Collection Tool & Sample & Location(s) & Study Phases \\
\hline $\begin{array}{l}\text { Key informant interviews with } \\
\text { experts, male Fulani pastoralists, } \\
\text { and traditional authorities }\end{array}$ & $\begin{array}{l}\mathrm{n}=26 \text { (members of govern- } \\
\text { ment, NGOs, community-based } \\
\text { organizations, research institutes, } \\
\text { academia, a private company, a } \\
\text { male elder from a Tindana lineage, } \\
\text { elders, and Chief of Winkogo) }\end{array}$ & $\begin{array}{l}\text { Government, NGO, and research } \\
\text { institute offices; Cafés in Tamale } \\
\text { and Bolgatanga; communities in } \\
\text { Talensi district }\end{array}$ & Phases 1,2 , and 3 \\
\hline $\begin{array}{l}\text { Focus group discussions (based on } \\
\text { natural resource mapping, histori- } \\
\text { cal timelines, and PGIS mapping } \\
\text { protocols) }\end{array}$ & $\begin{array}{l}\mathrm{n}=12 \text { (three each of female-only; } \\
\text { male-only; and younger people- } \\
\text { only, which included a mix of } \\
\text { young men and women) }\end{array}$ & Duusi, Namoligo, and Winkogo & Phases 1 and 3 \\
\hline $\begin{array}{l}\text { On-farm transect walks (house- } \\
\text { hold system diagrams) }\end{array}$ & $\mathrm{n}=3$ & Duusi & Phases 1 \\
\hline Community transect walks & $\mathrm{n}=3$ (one in each study site) & Duusi, Namoligo, and Winkogo & Phase 1 and 2 \\
\hline Semi-structured interviews & $\begin{array}{l}\mathrm{n}=78(42 \text { men, } 36 \text { women, of } \\
\text { which } 13 \text { were between } 18-35 \\
\text { years of age) }\end{array}$ & Duusi, Namoligo, and Winkogo & Phase 2 \\
\hline $\begin{array}{l}\text { Semi-structured interviews } \\
\text { (second round interviews with } \\
\text { community participants using } \\
\text { proportional piling protocol) }\end{array}$ & $\begin{array}{l}\mathrm{n}=21 \text { ( } 12 \text { men and nine women, } \\
\text { of which four were between } \\
18-35 \text { years of age) }\end{array}$ & Duusi, Namoligo, and Winkogo & Phase 3 \\
\hline $\begin{array}{l}\text { Semi-structured interviews (third } \\
\text { round interviews with community } \\
\text { participants using on-farm tran- } \\
\text { sect protocol) }\end{array}$ & $\begin{array}{l}\text { ( } n=9, \text { seven men and two } \\
\text { women, of which three were } \\
\text { between } 18-35 \text { years of age) }\end{array}$ & Duusi, Namoligo, and Winkogo & Phase 3 \\
\hline Informal conversations & $\begin{array}{l}\text { Community members and key } \\
\text { informants }\end{array}$ & $\begin{array}{l}\text { Duusi, Namoligo, and Winkogo; } \\
\text { district and regional government } \\
\text { offices }\end{array}$ & Phases 1,2 , and 3 \\
\hline Participant observation & $\begin{array}{l}\text { Field-based observations during } \\
\text { on-farm interviews and focus } \\
\text { group discussions, recorded daily } \\
\text { in field notes; overt observation of } \\
\text { FMNR Group pruning session at a } \\
\text { community FMNR site }\end{array}$ & Duusi, Namoligo, and Winkogo & Phases 1, 2, and 3 \\
\hline
\end{tabular}

Table 2. Study site communities in Talensi district with information on initial dates of FMNR implementation, site characterizations, and a brief characterization of livelihood bases for each community.

\begin{tabular}{|c|c|c|c|}
\hline Community & $\begin{array}{l}\text { Initial Date of FMNR } \\
\text { Implementation }\end{array}$ & Site Characterization & Livelihood Base \\
\hline Namoligo & 2009 & Rural & $\begin{array}{l}\text { Farming, livestock production, mining at the nearby conces- } \\
\text { sions, small-scale artisanal mining, shea production, labor } \\
\text { migration to towns in southern Ghana }\end{array}$ \\
\hline Winkogo & 2015 & Peri-urban & $\begin{array}{l}\text { Farming (including dry season vegetable farming), livestock } \\
\text { production, basket weaving, shea production, trade and infor- } \\
\text { mal wage labor in Bolgatanga Town, labor migration to towns } \\
\text { in southern Ghana }\end{array}$ \\
\hline Duusi & 2018 & Very rural & $\begin{array}{l}\text { Farming, livestock production, shea processing, small-scale } \\
\text { artisanal mining, shea production, labor migration to towns in } \\
\text { southern Ghana }\end{array}$ \\
\hline
\end{tabular}


knowledge, land and natural resource management, and local perceptions of land use change in Talensi. As with all focus group discussions conducted during this study, groups were separated into male-only, female-only, and youth-only (18-35 years of age, based on the African Union definition for youth) groups in order to capture any social differences in perspectives. Scoping informed the development of our semi-structured interview protocol, implemented in all three communities during the second phase of fieldwork.

\section{Second phase of data collection}

In June-July 2019, semi-structured interviews ( $\mathrm{n}=78,42$ men and 36 women, of which 13 were youth) were conducted across the three study communities and focused principally on understanding farmers' livelihoods and their perceptions regarding the benefits and trade-offs of practicing FMNR. We purposefully sampled members of the NGO-established FMNR and Fire Volunteer groups ( $\mathrm{n}$ $=47$, which included three senior men who allocated land for the community FMNR sites) and residents not affiliated with the NGO intervention $(n=31)$. The latter participants were identified through a snowballing approach, beginning with FMNR group members identifying someone in the community who was not part of the group. In order to avoid clustering our participant sample in specific sections of each community, we made sure, when possible, to sample farmers from multiple sections of communities, including sections further removed from primary roads. We interviewed two sedentarized Fulani pastoralists, both of whom played active roles in local government-supported farmer-herder dispute resolution in Talensi. These interviews collected data on pastoralist relationships with farming communities and herding strategies in the region.

\section{Third phase of data collection}

In January-February 2020, we conducted follow-up, semistructured interviews ( $\mathrm{n}=21,12$ men and nine women, of which four were youth) and then third round follow-up interviews ( $\mathrm{n}=9$, seven men and two women, of which three were youth) with participants from our community sample. These interviews were held to deepen our understanding of the benefits and trade-offs that participants perceived from practicing FMNR, as well as to validate our evolving hypotheses regarding social equity of FMNR. We also conducted focus group discussions $(n=9)$, using participatory GIS mapping, to expand on and validate our understanding of the local farming system and natural resource management in Talensi. A semi-structured interview protocol implemented with the Chief of Winkogo, a senior male from a Tindana lineage, and two senior men from Duusi and Namoligo collected data mainly on land and tree tenure. We could not interview the chiefs of Duusi or Namoligo as new ones had not yet been appointed following the deaths of previous incumbents.

\section{Data analysis}

All qualitative data were analyzed in NVivo 12 (QSR 2020), using open and deductive coding approaches (Bernard and Ryan 2010). As a multi-phased, qualitative study, data were analyzed concurrent with and following each phase (Bryman 2012). These data analysis approaches, which occurred in conjunction with our analysis of secondary literature, allowed for emergent themes to develop. Deductive coding of data allowed for targeted analysis of social equity relevant themes. Given the sensitivity of the community-level data under analysis in this paper, we at times withhold identifiers such as location to prevent attribution of politically sensitive views or opinions to specific individuals.

\section{Results and Discussion}

\section{Assessing social equity of FMNR}

We organize the following two sections based on where FMNR was being practiced: farmland and the community FMNR sites. The third section assesses how dominant political and environmental discourses shaped participation in the FMNR intervention as well as its ecological rationale. Our analysis underscores how contextual equity conditions distributive, procedural, and recognition dimensions of equity.

\section{Restoring degraded farmland with FMNR}

Research attributes to FMNR many restoration benefits for farmland (Reij and Garrity 2016, Bayala et al. 2020). However, we found that the potential for farmers to experience benefits of FMNR on-farm were socially differentiated and based largely on preexisting patterns of control over and access to naturally regenerating trees and shrubs. These social differences, which demonstrated how traditional tree and land tenure historically and contemporarily structured levels of land and natural resource authority, control, and access in northern Ghana (Poudyal 2011, Boffa 2015), were also conditioned by the spatial dimensions of the Talensi farming system.

The historical, socio-ecological, and political context of tree management was demonstrated by $P$. biglobosa, which produces a commercially valuable pod and is also a critical source of dry season nutrition. We found that traditional authorities, either the Tindana or chieftaincy, often controlled harvest rights to P. biglobosa. A key informant from a Tindana lineage directly attributed the historic political power of the Tindana in Talensi to its control over P. biglobosa, although he specified that in decades past most harvesting occurred in the bush-land now permanently settled and farmed. This finding mirrors those of Schreckenberg (1999) in Benin and Poudyal (2011) in northern Ghana who found that chiefs and sub-chiefs maintain harvest rights to P. biglobosa. Poudyal (2011) 
concluded that the inability of other farmers to benefit from $P$. biglobosa disincentivizes them from retaining seedlings on their farms and is possibly hastening the decline of $P$. biglobosa in the landscape. Research elsewhere in West Africa further demonstrates that attention should be paid to how local level resource hierarchies may create different social outcomes regarding who can benefit from the natural regeneration of specific tree species (Augusseau et al. 2006, Brottem 2011, Pehou et al. 2020).

We found that assessing where FMNR is being implemented, as well as changes within the local agroecological context, were important since social equity outcomes might be spatially differentiated. For example, from the perspective of some participants, bush farms were critical areas for FMNR because they were not continuously cropped and therefore allowed for more natural regeneration. Their perspective is supported by ecological evidence, which shows that most natural regeneration in the parklands occurs on bush farms and in fallows (Schreckenberg 1999, Boffa 2015). Given that cultivation rights to non-lineage bush farms in Talensi are based on leasehold agreements, inequities in access to the most economically valuable tree products were common. For example, in one case in Duusi, the tenant farmer was allowed to cultivate the land but prohibited from accessing any tree products, except for medicinals, which were governed as a common resource when used for domestic purposes in Talensi. In another case from Duusi, the tenant farmer could access fruit but not $V$. paradoxa nuts for domestic consumption or commercial production. As we learned from our youth-only and women-only focus groups, women and younger people relied in particular on bush farm cultivation since they experienced reduced access to village land for cropping. Women and youth, along with latecomers, therefore might be less likely to benefit from FMNR. As croplands expand and fallows decline - or are eliminated altogether-FMNR might be more suitable on bush farms (Binam et al. 2017), which therefore requires attention to spatially differentiated control over and access to naturally regenerating trees and shrubs for secondary rightsholders.

Along with gender, generation, and residence status, we found that class dimensions, specifically landholding and access to capital, conditioned who benefits from FMNR. For instance, large landholders might benefit more from FMNR because their landholdings are more likely to retain fallows (Binam et al. 2017, Iiyama et al. 2017), as we found to be the case with the three senior men who allocated land for community FMNR sites in Duusi and Namoligo. Across our study sites, multiple participants $(\mathrm{n}=13)$ indicated they could not practice FMNR due to the absence of living rootstock in their fields. This was a problem most common for those managing smaller landholdings or plots in villages, which was more likely the case for women and youth. In continuously cropped village fields, natural regeneration is more dependent on rates of seed dispersal (Lohbeck et al. 2020). However, if FMNR is used to promote the regeneration of trees and shrubs from seed, protection from browsing pressures becomes more important (Arnold and Dewees 1997). While we observed rudimentary protection for regenerating seedlings in farmers' fields and homegardens (such as mosquito nets supported by poles), most seedlings deliberately retained in village fields were unprotected. Purchasing protective material, such as mesh fencing, requires access to capital and this is likely to favor senior men, who are more likely wealthier.

Contextual inequities, rooted in traditional land and tree tenure regimes, might lead to the differential distribution of benefits from FMNR on-farm. However, many participants also remarked how their traditional agroecological practices shared similarities with FMNR on-farm, pointing in particular to the protection and management components of the land restoration approach. For instance, a young man from Namoligo explained how he learned from his father about how to weed around trees on his farm in order to protect them from fire, while another farmer referenced the thinning techniques they traditionally used to manage shrubs on farms. While FMNR is often characterized as supporting the natural regeneration of native tree species (Chomba et al 2020), participants in our study indicated using FMNR on exotics. Some farmers also reported using FMNR on trees growing from planted seed or seedling (both exotics and natives), reflecting changing NTFP preferences in the region. A key principle of FMNR is that it should be adapted to local knowledge and needs (Tougiani et al. 2009), and this was generally evident with regard to FMNR on-farm.

\section{Restoring communal land with FMNR}

While mainly used to restore farmland (Chomba et al. 2020), FMNR has also been implemented by NGOs to restore degraded woodlands and forests in Ghana and Ethiopia (Brown et al. 2011, Weston et al. 2015). FMNR in this context therefore shares similarities with assisted natural regeneration (ANR) (Haglund et al. 2011), which more often refers to a suite of approaches for regenerating secondary forests (Chazdon et al. 2020b). As with FMNR on-farm, we found that opportunities to benefit from community FMNR were influenced by historical, socio-ecological, and political dimensions, including tenure regimes. Additional inequities, both of which speak to procedural inequity, surfaced in FMNR project design. Community FMNR was also fundamentally different from FMNR on-farm due to an important distinction: while FMNR on-farm shared similarities with the traditional agroecological practices of farmers in our study, the community FMNR model derived wholly from the NGO intervention.

We found that an inequitable distribution of benefits from community FMNR was most likely to emerge because the sites remained embedded within preexisting land and 
tree tenure arrangements. For example, four research participants from one of our study communities indicated in interviews and informal conversations that the landallocating household maintained certain usufruct rights to the land. This included primary rights to harvesting $V$. paradoxa, which, in practice, meant that members of these households maintained the exclusive right to collect the $V$. paradoxa nuts. This contradicted the governance model promoted by the NGO, which was based on the principle that upon allocation, the land was to be managed as a common property resource. Furthermore, even though cultivation was not occurring at any of the community FMNR sites in our study communities, the four aforementioned participants stated that the land-allocating household maintained the right to cultivate the land, and two of the community FMNR sites had been cultivated in the past. Three participants (including a member of a land allocating household) highlighted improvements in soil fertility as an anticipated or experienced outcome of community FMNR. None of these three participants explicitly identified this as problematic or inequitable. However, this could lead to a scenario where, as observed in the community forestry literature (Nash and Luttrell 2006), the land-allocating household(s) and those living closest to the site derive greater benefit if in the future they reclaim the lands for cultivation-a possibility perceived by two participants. This would mean that the cost of restoring the land was borne by the community even though only a select few would derive direct benefit.

We further found that the process for selecting community FMNR sites was shaped by pre-existing hierarches in authority over land use decision-making. In our study communities, the community FMNR sites were allocated either by a household(s) from a firstcomer lineage or from a household within a lineage that, since it was also one of the earliest settling lineages, had a special relationship to the firstcomer lineage. This did not necessarily mean that all community FMNR sites were located on firstcomer lineage land. For instance, the section of Winkogo where we did research was comprised of latecomers and a community FMNR site was established there. However, according to the Chief of Winkogo, the decisions to allocate lands for the community FMNR sites in Winkogo (there were three in total) were made between him and firstcomer lineages. These decision-making processes excluded the latecomer lineages, even though they traced their initial settlement in the area to several hundred years ago.

Along with traditional authorities, other powerful actors, including international NGOs and states, make natural resource decisions which reflect unequal power relations (Colfer and Capistrano 2012, Libert-Amico and Larson 2020). These decisions might also contradict local perceptions of equity and traditional land and natural resource management practices (Martin et al. 2014, Gross-Camp et al. 2019). In our study, a general sentiment expressed by FMNR group members was that they expected to be financially compensated for restoring the community FMNR sites. The material impact of their dissatisfaction was revealed to us by our field observations, which were corroborated by the accounts of participants, that FMNR was used sparingly — if at all —-to manage the community FMNR sites once the NGO project ended. Underscoring the influence of tenure in farmer land management decision-making, two participants indicated that restoring communal land with FMNR ran counter to traditional land management practices as most land managed as a common was still held by households. Such land remained under communal management as long as the household maintaining rights to the land was not actively using it (such as for farming). These two participants considered FMNR to be most suitable for managing household farmlands, as farmers in these contexts-as opposed to commons - maintained greater control over trees and land use decision-making and therefore felt more incentivized to invest individual labor in tree management. The NGO's effort to rely on unpaid community labor most closely paralleled a 1980s initiative in northern Ghana, led by the government's Rural Forestry Division, which sought unpaid community participation in establishing village woodlots (Wardell 2020). Yet, as woodlots, community FMNR did not align with the traditional subsistence-based wood-fuel economy, which relied on rotational coppicing of species, most common in fallows-such as Piliostigma and Combretum-and the purchase of charcoal. While meeting local expectations in land and forest restoration is difficult, especially when they are financially based (Djenontin et al. 2020), more substantive involvement of community members in the FMNR project design might have led to more locally suitable applications of FMNR.

\section{Who frames equity? Thinking on a landscape scale}

Dominant political and environmental discourses shape patterns of inclusion and exclusion across broad spatial and temporal scales (Fairhead and Leach 1996, Robbins 2011, Davis 2020). Responding to the question of who frames equity (Figure 2), we draw on two examples from our research to consider how political and environmental discourses influenced the NGO's FMNR project design and implementation (see also Hansen et al. 2012). Both examples also point to the need to think on a landscape scale, which is salient for FMNR, given the interest in using the approach for restoring landscapes (Reij and Winterbottom 2015).

One point of divergence we found pertained to how the intervention in Talensi underappreciated the complex role of fire in land and natural resource management. Burning in mesic savannas is seasonal (Laris et al. 2018), and farmers in the parklands traditionally use fire to clear land, including fallows, where tree stumps are commonly left in 
coppice in order to facilitate natural regeneration (Boffa 1999). A recent study found that fire is positively associated with abundance of regeneration in parkland farm plots in Burkina Faso and Ghana (Lohbeck et al. 2020). Other dryland local resource managers, such as pastoralists, principally use fire to support the regeneration of grassland (Krätli 2015). However, the FMNR intervention in Talensi categorically supported fire suppression, based on the simplistic assumption that fire prevents natural regeneration (Weston et al. 2013). By perpetuating the narrative of "bush burning," in which all types of anthropogenic or natural fire caused degradation, the intervention reinforced decades-old fire suppression policies rooted in colonial era science (Amanor 2002). Given the ecologically and politically complex role of fire in savannas, there are ultimately a plurality of perspectives regarding its utility for managing landscapes (Kull 2016).

We found that the lack of participation of pastoralists in the FMNR intervention further demonstrated the power of environmental as well as political discourses. Farmer participants in our study generally supported the exclusion of mobile pastoralists from the FMNR intervention, including by prohibiting their access to natural resources on community FMNR sites (see also Weston et al. 2013). Some of these participants, along with key informants, largely placed the blame for bush fires on mobile pastoralists. However, pastoralists are key stakeholders in the landscape and they, like farmers, manage trees and shrubs, albeit with a focus on maximizing nutrient quality for livestock fodder (Krätli 2015). According to our interviews with Fulani pastoralists and key informants, cropland expansion has decreased available grazing areas, leading to increased farmer-herder conflict. Fulani in Ghana have historically been politically marginalized, ethnicized, and criminalized in a myriad of ways (Tonah 2002). Constitutionally, they are not recognized as citizens despite some Fulani populations having been settled in Ghana since the mid-19th century (Tonah 2002). The marginalization of Fulani in Ghana is so deeply entrenched that addressing the problem in its entirety is well beyond the scope of an FMNR intervention. However, their exclusion from participation in the FMNR intervention, rooted in historically constituted political and environmental framings, is socially inequitable and raises practical concerns for using FMNR to restore landscapes.

\section{Conclusion}

This paper drew on empirical evidence from a field study in northeastern Ghana to assess the social equity implications of an FMNR intervention. Drawing on the McDermott et al. (2013) social equity framework, we demonstrated how contextual inequities may influence FMNR project outcomes relating to the distribution of benefits, decisionmaking, and the recognition of plural and local agroecological knowledge systems. Our findings demonstrated the salience of preexisting hierarchies in authority, control, and access over land and trees for FMNR projects, as well as how these hierarchies might be spatially differentiated, based on the local farming system and agroecological change. Overall, our findings underscored how historical, socio-ecological, and political dimensions conditioned social equity of FMNR outcomes. We underscored inequities that were specific to the FMNR intervention in Talensi, including aspects of the community FMNR model and how pastoralists were largely excluded. This demonstrates that even in contexts where FMNR shares similarities with traditional agroecological knowledge and practices-such as in the West African parklands (Hansen et al 2012, Binam et al 2017) - inequities might still emerge, depending on how the FMNR project is designed and implemented. However, we also noted how distributional inequities rooted in traditional tree tenure regimes predated the intervention, and that addressing the historic political marginalization of pastoralists in Ghana fell outside the sphere of control of the NGO. Generally, our study contributes to the evidence base demonstrating that the social and political dimensions of land and forest restoration deserve more attention (Elias et al. 2021, Chazdon et al. 2020a), something particularly important given the ambitious aims of the UN Decade on Ecosystem Restoration.

One limitation to this study is that we only present findings from one case. It will therefore be important to expand the empirical evidence base in order to assess the transferability of our conclusions. A second limitation is that our research was conducted in northeastern Ghana, part of the West African parklands, where FMNR on-farm shares similarities with traditional agroforestry practices (Hansen et al 2012, Binam et al 2017). As FMNR is scaled out across Africa and south Asia (Francis et al. 2015), including in areas where components of FMNR might be less similar to the traditional practices of farmers (Moore et al. 2020), there might be aspects of our findings that are less transferrable. However, we feel that our key conclusions, particularly regarding how preexisting, local-level resource hierarchies conditioned social equity of FMNR, are likely to be salient elsewhere, as research in other fields demonstrates the impact of history and politics on environmental and development project outcomes (Mansuri and Rao 2012, Hajjar et al 2020).

To conclude, we offer several recommendations for practitioners, based on our findings. First, in line with earlier findings in the community forestry literature (McDermott and Schreckenberg 2009), we argue it is important that FMNR implementing agencies consider equity from the outset. This means recognizing the varying aspirations of different stakeholders in the landscape and putting in place the processes needed to overcome contextual inequity and achieve equitable distributive outcomes. Second, in line with recent calls to make restoration "people-centric" (van Noordwijk et al. 2020), we recommend recognizing 
and strengthening the participation of diverse local land users into FMNR project designs. Enhanced participation of local stakeholders might improve restoration outcomes, as demonstrated in related fields (Woodley et al. 2012, Oldekop et al. 2016). Third, conducting tenure assessments prior to implementation will allow for identifying which stakeholders in the landscape experience tenure insecurity, which evidence suggests is important for mitigating inequitable restoration outcomes (Mansourian et al. 2014, Cronkleton et al. 2017, McClain et al. 2020). The tenure diagnostic proposed by McClain et al. (2020), which was designed for use in Forest Landscape Restoration, is a model for such an assessment. Finally, if FMNR is paired with enrichment planting due to insufficient natural regeneration (Chomba et al. 2020), special attention needs to be paid to how tenure regimes condition control over and access to tree products, as well as whether planting a tree constitutes a claim of land authority, as is the case in many customary tenure systems (Boffa 2015).

\section{Acknowledgments}

We thank three anonymous reviewers, an Associate Editor, Marlène Elias, and Carolin Dieterle for their very helpful comments and suggestions at different stages of this article. We are also grateful to the editors of this special issue for inviting us to contribute this article. We thank Chengxiu Li and Michael Batame for their support in developing the map depicting our study area. Finally, we extend our deepest gratitude to the residents of northeastern Ghana who supported this study in their capacity as research participants. This work was funded through the "Building REsearch Capacity for sustainable water and food security In drylands of sub-saharan Africa" (BRECcIA) which is supported by UK Research and Innovation as part of the Global Challenges Research Fund, grant number NE/P021093/1.

\section{References}

Akaateba, M.A., 2019. The politics of customary land rights transformation in peri-urban Ghana: Powers of exclusion in the era of land commodification. Land Use Policy 88:1-10.

Amanor, K.S. 2002. Bushfire management, culture and ecological modernisation in Ghana. IDS Bulletin 33:65-74.

Arnold, J.E.M. and P.A. Dewees (eds). 1997. Farms, Trees and Farmers: Responses to Agricultural Intensification. London: Earthscan.

Augusseau, X., P. Nikiéma and E. Torquebiau. 2006. Tree biodiversity, land dynamics and farmers' strategies on the agricultural frontier of southwestern Burkina Faso. Biodiversity and Conservation 15:613-630.

Bayala, J., J. Sanou, H.R. Bazie, R. Coe, A. Kalinganire and F.L. Sinclair. 2020. Regenerated trees in farmers' fields increase soil carbon across the Sahel. Agroforestry Systems 94:401-15.

Baynes, J., J. Herbohn, C. Smith, R. Fisher and D. Bray. 2015. Key factors which influence the success of community forestry in developing countries. Global Environmental Change 35:226-238.

Bernard. H.R. 2000. Social Research Methods: Qualitative and Quantitative Approaches. London, UK: Sage.

Bernard, H.R. and G.W. Ryan. 2010. Analyzing Qualitative Data: Systematic Approaches. London, UK: SAGE.
Binam, J.N., F. Place, A.A. Djalal and A. Kalinganire. 2017. Effects of local institutions on the adoption of agroforestry innovations: Evidence of farmer managed natural regeneration and its implications for rural livelihoods in the Sahel. Agricultural and Food Economics 5:1-28.

Boffa, J.M. 1999. Agroforestry parklands in sub-Saharan Africa. FAO Conservation Guide No. 34. Food and Agriculture Organisation.

Boffa, J.M. 2015. Opportunities and challenges in the improvement of the shea (Vitellaria paradoxa) resource and its management. Occasional paper 24. Nairobi, Kenya: World Agroforestry Centre.

Brottem, L. 2011. Rediscovering "terroir" in West African agroforestry parklands. Society and Natural Resources 24:553-68.

Brown, D.R., P. Dettmann, T. Rinaudo, H. Tefera and A. Tofu. 2011. Poverty alleviation and environmental restoration using the clean development mechanism: A case study from Humbo, Ethiopia. Environmental Management 48:322-333.

Bryman, A. 2012. Social Research Methods. Oxford, UK: Oxford University Press.

Chazdon, R.L., S.J. Wilson, E. Brondizio, M.R. Guariguata and J. Herbohn. 2020a. Key challenges for governing forest and landscape restoration across different contexts. Land Use Policy. doi:10.1016/j.landusepol.2020.104854.

Chazdon, R.L., D. Lindenmayer, M.R. Guariguata, R. Crouzeilles, J.M.R. Benayas and E.L. Chavero. 2020b. Corrigendum: Fostering natural regeneration on former agricultural land through economic and policy interventions. Environmental Research Letters 15:043002.

Chomba, S., J. Kariuki, J.F. Lund and F. Sinclair. 2016. Roots of inequity: How the implementation of REDD+ reinforces past injustices. Land Use Policy 50:202-213.

Chomba, S., F. Sinclair, P. Savadogo, M. Bourne and M. Lohbeck. 2020. Opportunities and constraints for using farmer-managed natural regeneration for land restoration in sub-Saharan Africa. Frontiers for Global Change. doi:10.3389/ffgc.2020.571679.

Colfer, C.J.P. and D. Capistrano (eds). 2012. The Politics of Decentralization: Forests, People and Power. London, UK: Earthscan.

Cronkleton, P., J.M. Pulhin and S. Saigal. 2012. Co-management in community forestry: How the partial devolution of management rights creates challenges for forest communities. Conservation and Society 10:91-102.

Cronkleton, P., Y. Artati, H. Baral, K. Paudyal, M.R. Banjade, J.L. Liu et al. 2017. How do property rights reforms provide incentives for forest landscape restoration? Comparing evidence from Nepal, China and Ethiopia. International Forestry Review 19:8-23.

Davis, D.K. 2020. The Arid Lands: History, Power, Knowledge. Cambridge, MA: MIT Press.

Dietz, T., D. Millar, S. Dittoh, F. Obeng and E. Ofori-Sarpong. 2004. Climate and livelihood change in north east Ghana. Pages 149172 in A.J. Dietz, and R.R. Verhagen (eds) The Impact of Climate Change on Drylands: Environment \& Policy, vol 39. Dordecht, The Netherlands: Springer.

Djenontin, I.N.S., L.C. Zulu and A. Ligmann-Zielinska. 2020. Improving representation of decision rules in LUCC-ABM: An example with an elicitation of farmers' decision making for landscape restoration in central Malawi. Sustainability 12:5380.

Dumenu, W.K. and W.N. Bandoh. 2016. Exploitation of African rosewood (Pterocarpus erinaceus) in Ghana: A situation analysis. Ghana Journal of Forestry 32:1-15.

Edmunds, D. and E. Wollenberg (eds). 2003. Local Forest Management: The Impacts of Devolution Policies. London, UK: Earthscan. 
Elias, M., D. Joshi and R. Meinzen-Dick. 2021. Restoration for whom, by whom? Exploring the socio-political dimensions of restoration. Ecological Restoration 39:3-15.

Fairhead, J. and M. Leach. 1996. Misreading the African Landscape: Society and Ecology in a Forest-Savanna Mosaic. Cambridge, UK: Cambridge University Press.

Fortes, M. 1949. The Web of Kinship among the Tallensi. London, UK: Oxford University Press.

Fortmann, L. 1985. The tree tenure factor in agroforestry with particular reference to Africa. Agroforestry Systems 2:229-251.

Francis, R., Weston, P. and J. Birch. 2015. The social, environmental and economic benefits of farmer managed natural regeneration. World Vision Australia.

Gann, G.D., T. McDonald, B. Walder, J. Aronson, C.R. Nelson, J. Jonson et al. 2019. International principles and standards for the practice of ecological restoration. Restoration Ecology 27:S1-S46.

Gross-Camp, N.I. Rodriguez, A. Martin, M. Inturias and G. Massao. 2019. The type of land we want: Exploring the limits of community forestry in Tanzania and Bolivia. Sustainability 11:1643.

Haglund, E., J. Ndjeunga, L. Snook and D. Pasternak. 2011. Dry land tree management for improved household livelihoods: Farmer managed natural regeneration in Niger. Journal of Environmental Management 92:1696-1705.

Hajjar, R., J.A. Oldekop, P. Cronkleton, P. Newton, A.J.M. Russell and W. Zhou. 2020. A global analysis of the social and environmental outcomes of community forests. Nature Sustainability. doi:10.1038/s41893-020-00633-y.

Hansen, N.T., A. Ræbild and H.H. Hansen. 2012. Management of trees in northern Ghana-when the approach of development organizations contradicts local practices. Forests, Trees and Livelihoods 21:241-252.

Hart, K. 1971. Migration and tribal identity among the Frafras of Ghana. Journal of Asian and African Studies 6:21-36.

Iiyama, M., A. Derero, K. Kelemu, C. Muthuri, R. Kinuthia, E. Ayenkulu et al. 2017. Understanding patterns of tree adoption on farms in semi-arid and sub-humid Ethiopia. Agroforestry Systems 91:271-293.

Kandel, M., C. Benamba, R.S. Alare, G. Agaba and K. Schreckenberg. 2020. Scalable and equitable governance in farmer-managed natural regeneration. Pages 169-177 in N. Pasiecznik and C. Reij (eds) Restoring African Drylands. Wageningen, The Netherlands: Tropenbos International.

Kansanga, M., P. Andersen, D. Kpienbaareh, S. Mason-Renton, K. Atuoye, Y. Sano et al. 2019. Traditional agriculture in transition: Examining the impacts of agricultural modernization on smallholder farming in Ghana under the new Green Revolution. International Journal of Sustainable Development and World Ecology 26:11-24.

Kleeman, J., G. Baysal, H.N.N. Buley and C. Fürst. 2017. Assessing driving forces of land use and land cover change by a mixedmethods approach in north-eastern Ghana, West Africa. Journal of Environmental Management 196:411-442.

Konings, P. 1984. Capitalist rice farming and land allocation in northern Ghana. Journal of Legal Pluralism 22:89-120.

Krätli, S. 2015. Valuing Variability: New Perspectives on Climate Resilience Drylands Development. IIED.

Kull, C.A. 2016. Bushfire in Madagascar: Natural hazard, useful tool, and change agent. Pages 143-167 In G. Bankoff and J. Christensen (eds) Natural Hazards and Peoples in the Indian Ocean World. New York, NY: Palgrave Macmillan.
Kuusaana, E.D. and K.N. Bukari. 2015. Land conflicts between smallholders and Fulani pastoralists in Ghana: Evidence from the Asante Akim North District (AAND). Journal of Rural Studies 42:52-62.

Laris, P. and D.A. Wardell. 2006. Good, bad or 'necessary evil'? Reinterpreting the colonial burning experiments in the savanna landscapes of West Africa. Geographical Journal 172:271-290.

Laris, P., A. Jo and S.P. Wechsler. 2018. Effects of landscape pattern and vegetation type on the fire regime of a mesic savanna in Mali. Journal of Environmental Management 227:134-45.

Lentz, C. 2010. Is land inalienable? Historical and current debates on land transfers in northern Ghana. Africa: Journal of the International African Institute 80:56-80.

Libert-Amico, A. and A.M. Larson. 2020. Forestry decentralization in the context of global carbon priorities: New challenges for subnational governments. Frontiers for Global Change. doi:10.3389/ ffgc.2020.00015.

Lohbeck, M., P. Albers, L.E. Boels, F. Bongers, S. Morel, F. Sinclair et al. 2020. Drivers of farmer-managed natural regeneration in the Sahel: Lessons for restoration. Scientific Reports 10:15038.

Lovett, P. 2018. Agroforestry shea parklands of sub-Saharan Africa: Threats and solutions. LEAVES/PROFOR Background Paper. Washington, D.C.: International Bank for Reconstruction and Development/The World Bank.

Lund, C. 2008. Local Politics and Dynamics of Property in Africa. Cambridge, UK: Cambridge University Press.

Mansourian, S., L. Aquino, T.K. Erdmann and F. Pereira. 2014. A comparison of governance challenges in forest restoration in Paraguay's privately-owned forests and Madagascar's co-managed state forests. Forests 5:763-783.

Mansuri, G. and V. Rao. 2013. Localizing development: Does participation work? Washington D.C.: The World Bank.

Martin, A., N. Gross-Camp, B. Kebede, S. McGuire and J. Munyarukaza. 2014. Whose environmental justice? Exploring local and global perspectives in a payments for ecosystem services scheme in Rwanda. Geoforum 54:167-177.

McClain, R., S. Lawry, M.R. Guariguata and J. Reed. 2020. Toward a tenure-responsive approach to forest landscape restoration: A proposed tenure diagnostic for assessing restoration opportunities. Land Use Policy. doi:10.1016/j.landusepol.2018.11.053.

McDermott, M.H. and K. Schreckenberg. 2009. Equity in community forestry: Insights from North and South. International Forestry Review 11:157-170.

McDermott, M., S. Mahanty and K. Schreckenberg. 2013. Examining equity: A multidimensional framework for assessing equity in payments for ecosystem services. Environmental Science \& Policy 33:416-427.

Millar, D. 2003. Forest in Northern Ghana: Local knowledge and local use of forest. Sahel-Sudan environmental research initiative. Occasional Paper No. 15. Copenhagen: Sahel-Sudan Environmental Research Initiative.

Ministry of Lands and Natural Resources. 2016. Tree Tenure and Benefit Sharing Framework in Ghana. Accra, Ghana.

Ministry of Local Government and Rural Development 2017. District Profile, Talensi District Assembly (2017-21). Ghana.

Moore, E., T. van Dijk, A. Asenga, F. Bongers, F. Sambalino, E. Veenendaal et al. 2020. Species selection and management under farmer managed natural regeneration in Dodoma, Tanzania. Frontiers for Global Change 3:563364.

Nash, R. and C. Luttrell. 2006. Forest Policy and Environment Programme: Grey literature crisis to context: the fuelwood debate. UK: ODI Forest Policy and Environment Programme. 
Nunan, F., M. Menton, C. McDermott and K. Schreckenberg. 2018 Governing for ecosystem health and human wellbeing. Pages 159-73 in K. Schreckenberg, G. Mace, and M. Poudyal (eds) Ecosystem Services and Poverty Alleviation: Trade-Offs and Governance. London, UK: Routledge.

Oldekop, J.A., G. Holmes, W.E. Harris and K.L. Evans. 2016. A global assessment of the social and conservation outcomes of protected areas. Conservation Biology 30:133-141.

Pascual, U., J. Phelps, E. Garmendia, K. Brown, E. Corbera, A. Martin et al. 2014. Social equity matters in payments for ecosystem services. Bioscience 64:1027-1036.

Pehou, C.H., B. Djoudi, B. Vinceti and M. Elias. 2020. Intersecting and dynamic gender rights to néré, a food tree species in Burkina Faso. Journal of Rural Studies 76:230-39.

Poudyal, M. 2011. Chiefs and trees: Tenures and incentives in the management and use of two multipurpose tree species in agroforestry parklands in Northern Ghana. Society and Natural Resources 24:1063-1077.

QSR International Pty Ltd. 2020. NVivo v12 (released in March 2020) https://www.qsrinternational.com/nvivo-qualitative-dataanalysis-software/home.

Reij, C. and R. Winterbottom. 2015. Scaling up regreening: Six steps to success: a practical approach to forest and landscape restoration. Washington, D.C.: World Resources Institute.

Reij, C. and D. Garrity. 2016. Scaling up farmer-managed natural regeneration in Africa to restore degraded landscapes. Biotropica 48:834-843.

Ribot, J. 2004. Waiting for democracy: The politics of choice in natural resource decentralization. Washington, D.C.: World Resources Institute.

Rinaudo, T. 2007. The development of farmer managed natural regeneration. LEISA 23:32-34.

Robbins, P. 2011. Political Ecology: A Critical Introduction, 2nd edition. Chichester, UK: Wiley-Blackwell.

Schreckenberg, K. 1999. Products of a managed landscape: Nontimber forest products in the parklands of the Bassila region, Benin. Global Ecology and Biogeography 8:279-289.

Shepherd, G. 1992. Managing Africa's tropical dry forests: A review of indigenous methods. London, UK: Overseas Development Institute.

Smale M., G. Tappan and C. Reij. 2018. Farmer-manged restoration of agroforestry parklands in Niger. Pages 19-34 in F. Wouterse and O. Badlane (eds) Fostering Transformation and Growth in Niger's Agricultural Sector. The Netherlands: Wageningen Academic Publishers.

Soeters, S., R. Weesie and A. Zoomers. 2017. Agricultural investments and farmer-Fulani pastoralist conflict in West African drylands: A northern Ghanaian case study. Sustainability 9:2063.

Tonah, S., 2002. Fulani pastoralists, indigenous farmers and the contest for land in Northern Ghana. Africa Spectrum 37:43-59.

Tougiani, A., C. Guero and T. Rinaudo. 2009. Community mobilisation for improved livelihoods through tree crop management in Niger. GeoJournal 74:377-389.

Ubink, J.A. and J.F. Quan. 2008. How to combine tradition and modernity? Regulating customary land management in Ghana. Land Use Policy 25:198-213. van Noordwijk, M., V. Gitz, P.A. Minang, S. Dewi, B. Leimona, L. Duguma et al. 2020. People-centric nature-based land restoration through agroforestry: A typology. Land 9:251.

Wardell, D.A., A. Reenberg and C. Tøttrup. 2003. Historical footprints in contemporary land use systems: Forest cover changes in savannah woodlands in the Sudano-Sahelian zone. Global Environmental Change 13:235-254.

Wardell, D.A., 2005. Moving the boundaries of forest and land use history: the case of Upper East Region in northern Ghana. Pages 168-194 in Q. Gausset, M.A. Whyte and T. Birch-Thomsen (eds) Beyond Territory and Scarcity: Social, Cultural and Political Aspects of Conflicts on Natural Resource Management. Uppsala, Sweden: Nordiska Afrikainstitutet.

Wardell, D.A. 2020. Groundnuts and headwater protection reserves: Tensions in colonial forestry policy and practice in the Northern Territories of the Gold Coast. Pages 357-401 in V. Damodaran and R. D'Souza (eds) Commonwealth Forestry and Environmental History: Empire, Forests and Colonial Environments in Africa, the Caribbean, South Asia and New Zealand. Delhi, India: Primus Books.

Weston, P., R. Hong and V. Morrison. 2013. End-of-phase evaluation report. World Vision Australia/Ghana.

Weston, P., R. Hong, C. Kaboré and C.A. Kull. 2015. Farmer-managed natural regeneration enhances rural livelihoods in dryland West Africa. Environmental Management 55:1402-1417.

Woodley, S., B. Bertzky, N. Crawhill, N. Dudley, J.M. Londoño, K. MacKinnon et al. 2012. Meeting Aichi Target 11: what does success look like for protected area systems? Parks 18:23-36.

World Vision Australia. 2019. Evaluation brief: Farmer-managed natural regeneration (FMNR) project, Ghana. fmnrhub.com. au/wp-content/uploads/2019/11/Ghana-2018-Talensi-FMNREvaluation-Brief.pdf.

Matt Kandel (corresponding author), B44/R2015, School of Geography and Environmental Sciences, University of Southampton, Southampton SO17 1BJ, United Kingdom. m.kandel@soton.ac.uk.

Genevieve Agaba, School of Geography and Environmental Sciences, University of Southampton, Southampton, United Kingdom.

Rahinatu S. Alare, Department of Environmental Science, C.K. Tedam University of Technology and Applied Sciences, Navrongo, Ghana.

Thomas Addoah, SNV, Netherlands Development Organisation, Accra, Ghana.

Kate Schreckenberg, Geography Department, King's College London, London, United Kingdom. 